\title{
MORPHOLOGICAL MODIFICATIONS IN LITHUANIAN CHILD-DIRECTED SPEECH
}

\author{
Laura Kamandulyte
}

\begin{abstract}
Child-directed speech (CDS) is very important for the language development of a child. When talking to children adults modify their language by simplifying it and adapting it to the language acquisition stage of the child. Words and constructions that are used in CDS are aqcuired earlier by the child.

This paper analyses the morphological modifications of Lithuanian CDS.

The analysis proves that the most frequent morphological modifications of CDS include: 1 ) the higher frequency of verb tokens over noun tokens, 2) the low frequency of indefinite pronouns, demonstrative pronouns, and adjectives, and 3) the high frequency of diminutives and interjections.

Prevalence of the denominative parts of speech has been influenced by the cognitive function; the abundance of verbs is conditioned by short utterances. The high frequency of diminutives is related to pragmatic function, intimacy, and emotions.
\end{abstract}

Keywords: language acquisition, longitudinal corpus, premorphology, protomorphology, modularized morphology, register of CDS, input, Lithuanian

\section{Introduction}

Many studies emphasize that CDS differs from adult speech by phonetic (high tone, clear articulation), morphological (abundance of nouns, especially diminutives, and verbs), syntactic (limited vocabulary, short sentences, large number of interrogative sentences) and pragmatic features (many questions and references) (Cruttenden 1994, Dressler, Barbaresi 1994, Ferguson 1977, Harkness 1976, Snow 1994). 
CDS of the Lithuanian language is a new topic, and there has been little research in this field. Phonetic, lexical, and morphological features of Lithuanian CDS were briefly surveyed by Wójcik (1994). The researchers who have analysed acquisition of the Lithuanian language have also discussed the impact of adult speech on CDS. Savickiene (1999, 2000, 2003) described the features of CDS in regard to noun usage, whereas Wójcik (2000) described the usage of verbs in speech directed to children. There have been no other studies of CDS in Lithuania.

In 1977 Ferguson (1977: 232-235) noted three main functions of CDS:

1) the function of communication and self-expression. The structure of CDS is in large part a response to the need for improved communication when one of the participants has only a limited ability to use language normally.

2) the function of language teaching. The structure of CDS reveals some simplifications, and the complexity is gradually restored as the child's language progresses.

3) the function of socialization. CDS offers a means of identifying the social roles which the child must learn as requiring differential behaviour in his society.

According to Ferguson (1977), and due to these three functions, various CDS modifications appear, differentiating it from usual adult speech. One of the major modifications is considered to be the allocation of parts of speech differing from that of adult speech.

The goal of this paper is to analyse the characteristic morphological features of Lithuanian CDS and to discuss the relation between the morphological modifications in CDS and the child's age.

\section{Method}

Studies in child language and CDS are ambivalent - on the one hand there is psychology and, on the other, linguistics. It is typical of psycholinguistic research, such as psychological sciences, to analyse the individual data. In this study the method of longitudinal research is applied.

The study focuses on naturally recorded conversations of a mother and her child Rūta. The conversations were recorded by the mother, a graduate in Lithuanian philology, 3-4 times per week. She was instructed to possibly cover all kinds of everyday situations. Data collection started when the daughter was $1 ; 3^{1}$ and was continued until the daughter was 3;5. The mother recorded 35 hours of naturally occurring conversations at home and in other places (e.g. while on a visit and taking a walk) in situations of free play and everyday situations (e.g. eating, washing, and dressing). The data were transcribed in CHAT format and coded morphologically using the program CHILDES (MacWhinney 2000).

The analysis was carried out according to the child's different stages of language acquisition - premorphologic, protomorphologic, and modularized morphology (Dressler et al. 1995-1996; Dressler 1997). To illustrate these stages, the following ages were chosen: the premorphologic stage is represented by age $1 ; 7$, protomorphologic by age $1 ; 9$, and modularized morphology by age $2 ; 5 .^{2}$

1 The numerals show the child's age (e.g. 1;3 - 1 year 3 months).

2 The stages of acquisition were determined by I. Savickiene (1999). 
During the premorphologic stage, the imitation of utterances and mechanical repetitions are typical of children's speech. The rules of morphology are applied by analogy, and the basics of vocabulary are evident during protomorphology. The stage of modularized morphology of children's speech already shows the acquisition of morphological categories, composite sentences, and the use of various vocabularies.

The results of CDS were compared with the data of the analysis of conversations between the same informant and another adult. Five hours of conversations between the informant and the other adult (a friend of the informant) cover different conversational themes (everyday situations, work, and research). The data were transcribed and coded morphologicaly using the program CHILDES (MacWhinney 2000).

The CDS is comparable with ADS (adult-directed speech) because conversations were recorded in both cases in everyday situations, and in both cases the informant was communicating very intimately (with a daughter and a good friend). The results of CDS were compared with the results of typical ADS (when the ability of an addressee to use language is unlimited) because the modifications of CDS can be set when the language is compared with the typical language, which does not have any special modifications. Otherwise, one might argue that the feature of language may just be a peculiarity of the language of a certain speaker and does not have to be a pervasive feature of the CDS register (Remick 1976, Kempe et al., forthcoming).

Child language and CDS became the subject of research interest in Lithuania only a few years ago; therefore, there are not many recorded and transcribed data of child language and CDS. Also, the results can not be compared with the longitudinal data of the language of other informants. However, the studies on other languages show that the method of individual longitudinal data research is reliable for psycholinguistic studies.

\section{Quantitative analysis of morphological modifications}

The hypothesis of this study was that since special functions are typical of the register of CDS, they should be reflected by more or less abundant use of particular parts of speech.

\subsection{Inflected parts of speech}

All the denominative parts of speech (noun, adjective, verb, numeral, pronoun, adverb) are inflected in Lithuanian. They denominate things, phenomena, features, or actions. Because of these functions, denominative parts of speech are dominant in speech. It is natural that this tendency prevails in CDS because the usage of denominative parts of speech has been influenced by the cognitive function. The mother names the different things, actions, features and gives the child a new knowledge about the world. However, the distribution of denominative parts of speech in the speech of the mother differs according to the child's stage of language acquisition (see Table 1 ). 
Table 1. Distribution of inflected parts of speech

\begin{tabular}{|l|c|c|c|c|}
\hline & $\mathbf{1 ; 7}$ & $\mathbf{1 ; 9}$ & $\mathbf{2 ; 5}$ & with adult \\
\hline Part of speech & & \multicolumn{4}{|c|}{ Percentage among all words } \\
\hline Noun & $22 \%$ & $21.7 \%$ & $21.9 \%$ & $18.7 \%$ \\
\hline Adjective & $1.2 \%$ & $2.1 \%$ & $2.9 \%$ & $6.4 \%$ \\
\hline Numeral & $3.0 \%$ & - & $0.4 \%$ & $1.2 \%$ \\
\hline Pronoun & $10.8 \%$ & $15.4 \%$ & $13.0 \%$ & $14.7 \%$ \\
\hline Verb & $28.1 \%$ & $25.7 \%$ & $28.4 \%$ & $20 \%$ \\
\hline Adverb & $18.8 \%$ & $17.7 \%$ & $12.9 \%$ & $16 \%$ \\
\hline Total & $83.9 \%$ & $82.6 \%$ & $79.5 \%$ & $77 \%$ \\
\hline
\end{tabular}

Table 1 shows that verbs are most common in the mother's speech. Although this part of speech dominates in the conversations with adults as well, here its frequency is much lower than when speaking to the child. The percentage of verbs used in the CDS in different stages varies from $25.7 \%$ to $28.4 \%$, and when speaking to the adult $-20.0 \%$.

Such plentiful use of verbs in the CDS results from short utterances expressing short thoughts. The speech contains nouns and no recitation; the simple thought is often expressed by means of verbs, a noun, and an adverb or an official part of speech. For example:

(1a) Močiutè miega jau. 'The grandmother is sleeping already.' (1;7)

(1b) Net vystyklo nereikia? '[You] don't even need a diaper?' (1;9)

(1c) Meškučiai jau miega. 'Teddies are already sleeping.' (2;5)

Moreover, CDS contains many verbs and several question words and dictations, where no noun is used. For example:

(2a) Skaitai? 'Are you reading?' (1;7)

(2b) Padainuok dar. 'Sing:IMP more.' (1;7)

(2c) Ka nori daryti? 'What do [you] want to do?' $(1 ; 9)$

(2d) Nusiprausk. 'Wash yourself.' (1;9)

(2e) Ko tu nori? 'What do you want?' $(2 ; 5)$

(2f) Truputi garsiau šnekèk. 'Speak:IMP a little bit louder.' (2;5)

The domination of verbs in CDS is determined by the heavy use of short utterances, regulations, and questions. It proves the claim by Ferguson (1977: 232) that the communicative function is the most important function of the register of simplified CDS. Adults, when communicating with children, try to be understood when noting, asking, or chatting in short and simple verbal clauses. Therefore, the difference between the usage of verbs and nouns in CDS is much greater than in speech among adults. In the mother's conversation with the child the difference in the percentage of verbs and nouns (difference $=$ verb\%-noun\%) ranges from 4 to 7 , whereas in the conversation with an adult it is 1 . Thus, more frequent use of verbs and less frequent use of nouns can be considered as characteristic features of CDS.

In regard to nouns, it is important to mention that one of the most important features of CDS is the frequent use of diminutives - from $47 \%$ to $64 \%$ of all nouns and from $10 \%$ to $14 \%$ of all words (see Figure 1, Figure 2). 


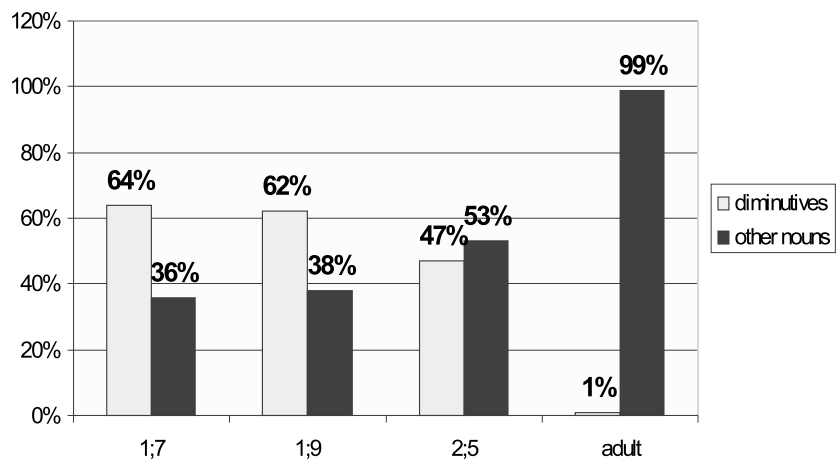

Figure 1. Distribution of diminutives among all nouns

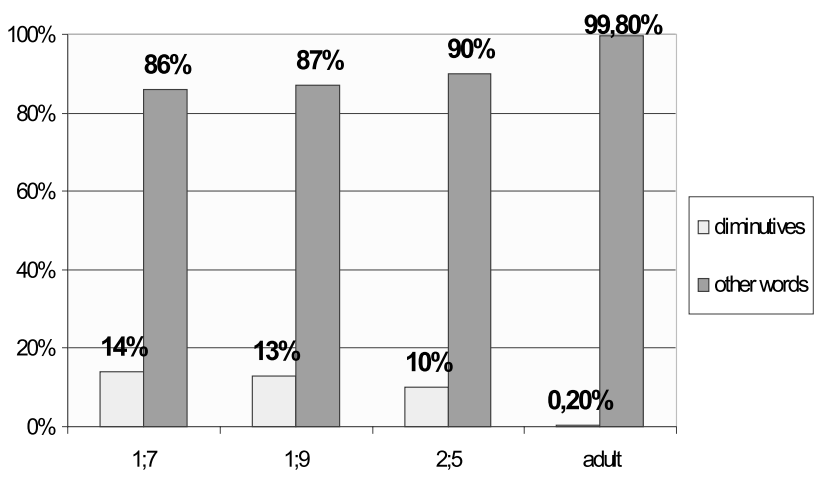

Figure 2. Distribution of diminutives among all words

The use of diminutives in CDS is related to pragmatic functions. Since the register of CDS is characterized by intimacy and emotion, the abundance of diminutives is not surprising. Although diminutives in the Lithuanian language are longer than their basic forms, according to V. Kempe (in press), their usage does not contravene the CDS as a mode of the simplified register Diminutives are not only important for the process of segmentations where the meaning of a noun is emphasized by its suffix form; they simplify the system of the language as well. The diminutive forms of all the twelve noun paradigms in the Lithuanian language obtain the flexions of only three paradigms: the first (inflection -as), the third (inflection -is), and the eighth (inflection $-\dot{e}$ ) (Savickienè 2003). Moreover, the diminutive suffixes in the Lithuanian language are always stressed, this way attracting the child's attention and helping him/her to acquire diminutive nouns faster.

The diminutives used by the mother mainly name people, toys, food, animals, parts of the body, clothing, furniture, and abstractions that are known to the child (Savickienè 2003). The majority of diminutives in the mother's speech relate to the naming of people (see Table 2). Nearly all of these diminutives are proper nouns modified to express tenderness and emotion. For example: 
(3a) O ka Rūtytè myli? 'What does Rūtytè:PNOUN:DIM love?'

(3b) O šiandien matei Akvilytę? 'Have [you] seen Akvilytė:PNOUN:DIM: ACC today?' (1;9)

Table 2. Distribution of diminutives

\begin{tabular}{|l|c|c|c|c|}
\hline & $\mathbf{1 ; 7}$ & $\mathbf{1 ; 9}$ & $\mathbf{2} ; \mathbf{5}$ & with adult \\
\hline Common nouns & $54 \%$ & $75 \%$ & $74 \%$ & $100 \%$ \\
\hline Proper names & $46 \%$ & $25 \%$ & $26 \%$ & - \\
\hline Total & $121(100 \%)$ & $110(100 \%)$ & $99(100 \%)$ & $2(100 \%)$ \\
\hline
\end{tabular}

As Table 2 shows, diminutive proper nouns in the informant's speech were most frequently used during the first analysed stages $(46 \%-1 ; 7)$. Later the diminutive forms of proper nouns were used more seldom while diminutive common nouns became more frequent. The percentage of diminutive self-entitling nouns decreases as well. During the first stages the informant often calls herself by using diminutives. For example:

(4a) Kur mamyte்? 'Where is Mummy?' (1;7)

(4b) Duok, mamyte išgers. 'Give [me], mummy will drink.' (1;9)

As the child's language acquisition increases, diminutives are replaced by pronouns, and the function of speech simplification becomes less important.

Diminutive adjectives and adverbs are rarely used in CDS. This tendency is typical of adult speech as well.

The study of the diminutives in the mother's speech revealed that each stage of CDS is characterized by frequent use of common words - diminutives. Diminutive proper nouns are used in the mother's speech only in the early stages of the child's speech acquisition (during the stages of premorphology and modularized morphology).

Frequent use of adverbs (as well as of pronouns) in CDS is determined by short verbal utterances. The majority of the adverbs are used during the first stages of the child's speech acquisition (18.8\% - see Table 1). Later the number decreases. It has been noticed that the decline of adverbs in the CDS is influenced by the decreased frequency of the use of the interrogative adverbs where, how, and why, which are very frequent during the early stages (see Table 3 ).

Table 3. Distribution of adverbs

\begin{tabular}{|l|c|c|c|c|}
\hline & $\mathbf{1 ; 7}$ & $\mathbf{1 ; 9}$ & $\mathbf{2 ; 5}$ & with adult \\
\hline Interrogative & $24 \%$ & $19 \%$ & $16 \%$ & $5 \%$ \\
\hline Other & $76 \%$ & $81 \%$ & $84 \%$ & $95 \%$ \\
\hline Total & $169(100 \%)$ & $154(100 \%)$ & $129(100 \%)$ & $236(100 \%)$ \\
\hline
\end{tabular}

When communicating with a smaller child, interrogative utterances dominate the CDS. They are used with the intention to involve the child in a conversation and to encourage him/her to speak. For example:

(5a) Kaip tu gyveni, Rūtuže? ‘How are you, Rūtužè:PNOUN:DIM?’ (1;7)

(5b) Kur tu bégi? 'Where are you running?' $(1 ; 7)$ 
Thus, one of the main features of CDS could be frequent use of adverbs during the early stages of language acquisition.

During the later stages of the child's language acquisition the use of interrogative adverbs decreases. More adverbs denoting character, location, and time are used. For example:

(6a) Dabar bus gerai. 'Now [it] will be good.' (2;5)

(6b) Teisingai. '[It] [is] right.' (2;5)

(6c) Čia bus gerai. '[It] will be good here.' $(2 ; 5)$

The child's conception of space and time during the stages of protomorphology and modularized morphology contributes to the increased use of a wider variety of adverbs in the mothers' speech. When the child accumulates some elements of morphology and a rich vocabulary, less attention is paid to teaching and naming particular denotations and to interrogative adverbs, and more emphasis is placed on communication and adverbial words determining space and time.

Table 1 shows that CDS is full of pronouns. The percentage of pronouns during the latest analysed stage is higher than that of the first stage and is more similar to that of adult speech. However, besides this tendency to increased pronoun use, there is another important tendency that is related to the meanings of the pronouns. The frequent use of some pronouns results from intimate conditions of communication, familiar atmosphere (you, I, yours, mine, for you, for me), and the function of CDS to acknowledge the world via questions (what?, who?). Table 4 presents the distribution of meanings of pronouns used in various stages.

Table 4. Distribution of pronouns

\begin{tabular}{|l|c|c|c|c|}
\hline & $\mathbf{1 ; 7}$ & $\mathbf{1 ; 9}$ & $\mathbf{2 ; 5}$ & with adult \\
\hline Personal & $43 \%$ & $40 \%$ & $51 \%$ & $41 \%$ \\
\hline Demonstrative & $3 \%$ & $7 \%$ & $12 \%$ & $17 \%$ \\
\hline Interrogative & $38 \%$ & $42 \%$ & $18 \%$ & $10 \%$ \\
\hline Indefinite & $16 \%$ & $11 \%$ & $19 \%$ & $33 \%$ \\
\hline Total & 97 & 134 & 130 & 217 \\
\hline
\end{tabular}

Table 4 shows that the most frequently used pronouns in the CDS are personal pronouns. The percentage of personal pronouns used in some stages is significantly higher than in the speech of adults ( $51 \%$ at age $2 ; 5-41 \%$ with the adult). It is caused by the intimate atmosphere of communication and the narrowness of the child's world where the most important people are the child and the mother. Whereas in the CDS no increased or decreased tendency was observed in the use of pronouns carrying this meaning, it is possible to claim that the use of such pronouns is an important feature of CDS regardless of the child's age.

Interrogative pronouns constitute another group of pronouns typical of CDS. The mother uses these pronouns especially often during the first stages of language acquisition (38\%-42\%). For example:

(7a) Kas čia yra? 'What is it?' $(1 ; 7)$

(7b) Ka daro tevelis dabar? 'What is the father doing now?' $(1 ; 9)$ 
Later, more active participation of the child in conversation and less frequent questions from the mother result in the decreased use of interrogative pronouns. However, even during the last analysed stage of CDS, the percentage of interrogative pronouns is much higher than in the speech with the adult (18\% at age 2;5-10\% with the adult).

The CDS uses indefinite pronouns not very often (19\% at age 2;5 - 33 \% with the adult). Although in the speech of adults it is the second biggest notional group of pronouns, it is not so frequent when speaking with children. It is more difficult for children to conceive indefinite pronouns, as they do not define concrete things or persons. Therefore, the indefinite pronouns in the mother's speech are used more often during the stage of modularized morphology. For example:

(8a) Nerra nieko ten. 'There is nothing there.' (2;5)

(8b) Va šitoj mažutëj knygutëj šuniukas yra kur nors nupieštas. 'The dog: DIM is painted somewhere in this small:DIM book:DIM.' (2;5)

However, even in this stage, the percentage of indefinite pronouns differs significantly from that in adults speech (19\% at age $2 ; 5-33 \%$ with the adult).

In the early CDS the demonstrative pronouns are rare $(3 \%-1 ; 7)$. Their use in the mother's speech depends on the child's age. During the last stage it already reaches a higher percentage (12\% at age $2 ; 5)$. For example:

(9a) Va, šita graži knyguté, pažiūrèk. 'Look, this is a nice book:DIM.'

(9b) Nori šita lèlytę paguldyt? 'Do you want to put this doll:DIM to bed?' $(2 ; 5)$

It is interesting to note that the demonstrative pronoun tai 'that' predominates in the speech of adults, whereas tas 'this' predominates in CDS. This is due to the limitation of the child's atmosphere and the need to define objects of the world around.

Adjectives are rarely used in CDS. Even during the stage of modularized morphology the use of adjectives in the mother's speech makes up less than $3 \%$ (2,9\% at age 2;5). Mainly adjectives with positive connotations, such as 'beautiful', 'small' and 'good', are used. This part of speech only describes and does not provide any new information. Consequently, it is rarely used.

The other part of speech rarely used in CDS is that of numerals. Its concrete meaning results in infrequent use in special cases. The most frequently used numeral in the speech of the informant is 'one'. It constitutes the opposition to the adverb a lot; therefore, it is used more often than other numerals.

The usage tendencies of denominative parts of speech in CDS are determined by the age of the child participating in the communication. The smaller the child the more denominative parts of speech naming concrete things and actions are used in the mother's speech. With the growth of the child the percentage of the denominative parts of speech decreases. 


\subsection{Uninflected parts of speech}

Uninflected parts of speech (preposition, particle, conjunction, interjection) do not have any entitling meaning. They connect the denominative parts of speech. Only prepositions distinguish themselves from the other uninflected parts of speech because they are often required by verbs. Particles or conjunctions can almost always be skipped. For these reasons, one can expect few particles and conjunctions in CDS, which is considered as a simplified register.

According to Paulauskienè (1994), interjections are not necessary for communication because they do not carry any information. However, the researchers of CDS are of the opinion that such emotionally expressive words are very important in the speech of children. They do not only express joy or dissatisfaction; they also convey certain information. They are holophrases, which often have the meaning of the whole sentence. Since the meaning of interjections in CDS is very significant, it is expected that in CDS these parts of speech also have a significant communicative function. Table 5 shows the regularity of usage of all uninflected parts of speech.

Table 5. Distribution of uninflected parts of speech

\begin{tabular}{|l|c|c|c|c|}
\hline Parts of speech & $\mathbf{1 ; 7}$ & $\mathbf{1 ; 9}$ & $\mathbf{2 ; 5}$ & with adult \\
\hline Prepositions & $1.2 \%$ & $1.4 \%$ & $1.9 \%$ & $5.1 \%$ \\
\hline Particles & $5.1 \%$ & $4.7 \%$ & $4.2 \%$ & $9.3 \%$ \\
\hline Conjunctions & $5.9 \%$ & $7.4 \%$ & $8.5 \%$ & $8.1 \%$ \\
\hline Interjections & $4 \%$ & $4 \%$ & $6 \%$ & $1 \%$ \\
\hline Total & $12.2 \%$ & $13.5 \%$ & $14.6 \%$ & $22.5 \%$ \\
\hline
\end{tabular}

It is interesting to note that the use of particles and conjunctions, contrary to our expectations, is not low. The conjunctions or particles serve the functions of intonation, expression, and drawing attention but not the function of conjoining. For example:

(10a) O kodèl tu bégai? 'And why were you running?' (1;7)

(10b) Ir gulès lèlytè. 'And the doll:DIM will lie.' (1;9)

Several particles and conjunctions dominate CDS - and, but, this, and here - which have the constant function of adding emphasis and stress. The particle but is often used to intensify questions.

Comparison of the percentage rates of CDS and adult speech in Table 5 shows that the informant uses more interjections in CDS than when speaking to the adults (2.6\% at age $1 ; 7 ; 2.8 \%$ at age $1 ; 9 ; 4.1 \%$ at age $2 ; 5$ and $0.1 \%$ with adult). For example:

(11a) Rūtyte, duok ir pasakyk labas. 'Rūtyte, give and say hello.' (1;7)

(11b) Sakyk ačiū, gerai. 'Say, thank you, fine.' (1;9)

The most frequently used interjections are thanks, welcome, hi, and alio, reflecting the educational function - the mother teaches her daughter phases of politeness. When communicating with a child, such phrases serve not only as indicators of 
politeness; they also have the function of mutual relation, support of communication, and attraction of attention.

In conclusion, use of interjections is a typical feature of CDS. These emotionalexpressive parts of speech are important not only as factors of particular meaning but also as the means of supporting the communicative act.

\section{Conclusion}

After the study of conversations of the mother both with her daughter and with other adults it is possible to conclude that the most frequent morphological modifications of CDS include:

1) higher frequency of verb tokens over noun tokens,

2) low frequency of indefinite, demonstrative pronouns and adjectives,

3) high frequency of diminutives and interjections.

The prevalence of the denominative parts of speech has been influenced by the cognitive function, and the abundance of verbs is conditioned by short utterances. The high frequency of diminutives in CDS is related to pragmatic function, intimacy, and emotion.

Also, the hypothesis that since the special functions are typical of the register of CDS, they should be reflected by more or less frequent use of particular parts of speech, was confirmed.

The morphological modifications in CDS can be divided into two groups:

1) modifications independent of the child's age, and 2) modifications dependent on the child's age. Independent modifications are the features of CDS that do not depend on the stage of language acquisition (use of diminutives). Dependent modifications are the features of CDS that develop in their frequency and character together with the child's age (distribution of parts of speech).

\section{References}

Cruttenden, Alan 1994. Phonetic and prosodic aspects of baby talk. - C. Gallaway, B. J. Richards (Eds.). Input and Interaction in Language Acquisition. Cambridge University Press, $135-152$.

Dressler, Wolfgang U. 1997. Zur Entstehung der Distinktivität in der Kindersprache. Polyphonie pour Ivan Fonagy. Jean Perrot (Ed.). Paris, Canada: Editions L'Harmattan.

Dressler, Wolfgang U.; Drążyk, R. D.; Dziubalska-Kołaczyk, K.; Jagła, E. 1995-1996. On the earliest stages of acquisition of polish declension. - Wiener Linguistische Gazette, Vol. 53-54, 1-21.

Dressler, Wolfgang U.; Barbaresi, Merlin L. 1994. Morphopragmatics. Diminutives and Intensifiers in Italian, German and other Languages. Trends in Linguistics: Studies and Monographs. Berlin.

Ferguson, Charles A. 1977. Baby talk as simplified register. - C. E. Snow, C. A. Ferguson (Eds.). Talking to Children: Language Input and Acquisition. Cambridge University Press.

Harkness, S. 1976. Mother's language. - W. von Raffler-Engel, Y. Lebrun (Eds.). Baby Talk and Infant Speech. Amsterdam: Swets; Zeitlinger B. V., 110-112. 
Kempe, Vera; Brooks, Patricia J.; Gillis, Steven (forthcoming). Diminutives provide multiple benefits for language acquisition.

MacWhinney, B. 2000. The CHILDES Project: Tools for Analyzing Talk. Vol. I: Transcription, Format and Programs. Mahwah, NJ: Erlbaum.

Paulauskienè, Aldona 1994. Lietuvių kalbos morfologija. Vilnius: Mokslo ir enciklopedijų leidykla.

Remick, H. 1976. Maternal speech to children during language acquisition. - W. von RafflerEngel, Y. Lebrun (Eds.). Baby Talk and Infant Speech. Amsterdam: Swets; Zeitlinger B. V., 223-233.

Savickienė, Ineta 1999. Lietuvio vaiko daiktavardžio morfologija. PhD Thesis. Kaunas: Vytauto Didžiojo universitetas.

Savickiené, Ineta 2000. Linksniai šnekamojoje kalboje. - Darbai ir dienos 24, 89-99.

Savickienė, Ineta 2003. The Acquisition of Lithuanian Noun Morphology. Wien: Verlag der Österreichischen Akademie der Wissenschaften.

Snow, Catherine E. 1994. Beginning from baby talk: twenty years of research on input in interaction. - C. Gallaway, B. J. Richards (Eds.). Input and Interaction in Language Acquisition. Cambridge University Press, 3-12.

Wójcik, Paweł 1994. Some characteristics features of Lithuanian baby talk. - Linguistica Baltica 3, 71-86.

Wójcik, Paweł 200o. The Acquisition of Lithuanian Verb Morphology: A Case Study. Krakow: Quartis.

Laura Kamandulyte, Department of the Lithuanian Language at Vytautas Magnus University, research interests: corpus linguistics, psycholinguistics, first language acquisition, second language acquisition,

language impairment.

I.kamandulyte@hmf.vdu.lt 


\section{LEEDU HOIDJAKEELE MORFOLOOGILISED MODIFIKATSIOONID}

\section{Laura Kamandulyte}

Vytautas Magnuse nimeline Kaunase Ülikool

Artiklis analüüsitakse leedu hoidjakeelele omaseid morfoloogilisi jooni ja nende seost lapse vanusega.

Hoidjakeelel on väga oluline roll lapse arengus. Lastega räkides lihtsustavad täiskasvanud oma keelekasutust ja kohandavad seda vastavalt keeleomandamise perioodile. Hoidjakeeles kasutatavaid sõnu ja konstruktsioone omandavad lapsed varem.

Ema ja tütre dialoogi analüüs lapse eri keeleomandamisperioodidel (premorfoloogiline, protomorfoloogiline, modulaarmorfoloogiline periood) näitab, et hoidjakeele morfoloogilised erijooned tulenevad sellistest keele funktsioonidest nagu kognitiivne ja emotiivne funktsioon, tähistus-, kasvatus-, lihtsustusfunktsioon.

Sagedamateks morfoloogilisteks modifikatsioonideks hoidjakeeles on: 1) verbide suurem esinemissagedus substantiividega võrreldes, 2) indefiniit- ja demonstratiivpronoomenite ning adjektiivide madal esinemissagedus, 3) deminutiivide ja interjektsioonide suhteliselt kõrge sagedus. Täistähenduslike sõnade domineerimine tuleneb kognitiivsest funktsioonist, verbide rohkus lausete lühidusest. Deminutiivide sage kasutamine seostub pragmaatilise funktsiooni, intiimsuse ja emotsionaalsusega.

Osa hoidjakeele erijooni ei sõltu lapse keeleomandamisperioodist, osa sõltub. Esimeste hulka kuulub deminutiivide kasutamine, teiste hulka teatud sõnaliikide eelistamine.

Võtmesõnad: keele omandamine, longitudinaalne korpus, premorfoloogia, protomorfoloogia, modulaarmorfoloogia, hoidjakeel, sisendkeel, leedu keel 